\title{
Effects of feed supplementation with various zinc sources on mineral concentration and selected antioxidant indices in tissues and plasma of broiler chickens
}

\author{
Oksana Ivanišinová, L’ubomíra Grešáková, Miroslav Ryzner, Vladimíra Ocel’ová,
Klaudia Čobanová \\ Slovak Academy of Sciences, Institute of Animal Physiology, Košice, Slovak Republic \\ Received November 6, 2015 \\ Accepted August 31,2016
}

\begin{abstract}
The aim of this study was to compare the effects of organic dietary zinc ( $\mathrm{Zn})$ sources and zinc sulphate on mineral deposition, activity of total superoxide dismutase (SOD) and copper/ zinc SOD in tissues of broiler chickens. The performance indicators and lipid peroxidation by measuring the contents of thiobarbituric acid reactive substances (TBARS) in tissues and plasma were also evaluated. Broilers were assigned to 4 treatment groups, each replicated $\times 6$, with 9 birds per replicate. The control group was fed conventional basal diet (BD); the three other groups received identical BD supplemented with $120 \mathrm{mg} \mathrm{Zn} / \mathrm{kg}$ in the form of zinc sulphate, zinc chelate of glycine hydrate (Zn-Gly), and zinc proteinate (Zn-Pro), respectively. After 5 weeks of dietary treatment, feed supplementation with $\mathrm{Zn}$ sulphate resulted in significantly higher average daily weight gain and final body weight, as well as improved feed conversion ratio compared to the Zn-Gly group. Intake of Zn-Pro significantly increased SOD activity $(P<0.05)$ in erythrocytes and lipid peroxidation $(P<0.01)$ in plasma. Activities of total SOD and $\mathrm{Cu} / \mathrm{Zn}$ SOD in liver and kidney were not affected by $\mathrm{Zn}$ supplementation. Addition of $\mathrm{Zn}$ supplements to broiler diets did not influence concentrations of zinc, manganese and copper in plasma, liver, kidney or breast muscle, with the exception of $\mathrm{Zn}$ deposition in the liver being significantly higher $(P<0.05)$ in the Zn-Pro supplemented group. Results of our study show that organic zinc sources have effects comparable to inorganic zinc sulphate in broilers fed diets containing a higher $\mathrm{Zn}$ content.
\end{abstract}

Zinc chelate, tissue deposition, superoxide dismutase, lipid oxidation, poultry

Appropriate mineral feed supplementation is required for many physiological functions and can improve growth performance and health of chickens for fattening. Zinc is known to be an essential microelement influencing immune functions, gene expression, cell proliferation, growth, and fertility. Being an essential part of more than 300 known enzymes, zinc directly participates in metabolic pathways and is one of major components of cell defence against oxidative stress as an integral part of cytosolic $\mathrm{Cu} / \mathrm{Zn}$ superoxide dismutase (Cu/Zn SOD) (Zago and Oteiza 2001; McDowell 2003).

Recently, organic sources of $\mathrm{Zn}$ have been introduced into animal nutrition due to their potentially higher bioavailability compared to the traditionally used inorganic forms. However, study results regarding the bioavailability of organic chelates remain controversial. Several studies show that organic $\mathrm{Zn}$ sources are more available to animals (Yenice et al. 2015; Sahraei et al. 2013; Yu et al. 2010; Rupić et al. 1997), contribute to elevation of $\mathrm{Cu} / \mathrm{Zn} \mathrm{SOD}$ activity in chicken liver (Ma et al. 2010) and improve growth performance of broilers (Feng et al. 2010). In contrast, other results indicate that organic chelates are comparable to standard $\mathrm{Zn}$ sulphate (Cao et al. 2000). Use of organic sources of trace elements (i.e. chelated amino acids, proteinates) in animal nutrition may prevent minerals from creating indigestible complexes with some dietary compounds, and reciprocal mineral antagonisms in the intestine which could reduce their absorption rate (Swiatkiewicz et al. 2014).

The current study was conducted to compare the effects of organic $\mathrm{Zn}$ sources with

Address for correspondence:

RNDr. Klaudia Čobanová, PhD.

Institute of Animal Physiology

Slovak Academy of Sciences

Šoltésovej 4-6, 04001 Košice, Slovak Republic

Phone: +421557922965

E-mail: boldik@saske.sk

http://actavet.vfu.cz/ 
inorganic $\mathrm{Zn}$ sulphate supplemented to conventional broiler diet for 5 weeks on the deposition of $\mathrm{Zn}, \mathrm{Cu}$ and $\mathrm{Mn}$ as well as the activities of total and $\mathrm{Cu} / \mathrm{Zn} \mathrm{SOD}$ in tissues. Moreover, the extent of lipid peroxidation in plasma, liver and kidney measured as TBARS level was determined in broilers fed with a higher content of dietary $\mathrm{Zn}$, and performance indicators were monitored during the whole experiment as well.

\section{Materials and Methods}

The experiment was carried out on a total of 216 broiler chickens (ROSS 308) obtained from a commercial hatchery (Budmerice, Slovakia). One-day-old chicks of both sexes were weighed and assigned to 4 treatment groups with each containing 6 replicates. Based on the body weight (BW), nine chicks were allotted to each replicate cage resulting in a similar mean initial BW per replicate. Birds of all groups received identical basal diet (BD) formulated to meet the requirements for broiler chickens (NRC 1994). All chicks were fed the starter diet from 1 to 19 days of age followed by the grower diet from 20 to 35 days of age. The BD applied in our

Table 1. Ingredients and chemical composition of basal diet fed to broiler chickens.

\begin{tabular}{lcc}
\hline Item & Starter diet (Days 1 to 19) & Grower diet (Days 20 to 35) \\
\hline Ingredient $(\%)$ & & \\
Maize, ground $(9 \% \mathrm{CP})$ & 41.96 & 42.13 \\
Soybean meal, extracted $(48 \% \mathrm{CP})$ & 28.00 & 30.00 \\
Wheat, ground $(12 \% \mathrm{CP})$ & 22.00 & 22.00 \\
Maize gluten $(67 \% \mathrm{CP})$ & 3.00 & - \\
Limestone & 1.50 & 1.40 \\
Monocalcium phosphate & 1.30 & 1.30 \\
Sunflower oil & 1.00 & 2.00 \\
Premix & 0.30 & 0.30 \\
Feed salt & 0.40 & 0.40 \\
Lysine & 0.35 & 0.25 \\
DL-Methionine & 0.17 & 0.20 \\
Allzyme $\mathrm{SSF}-\mathrm{poultry}$ & 0.02 \\
Nutrient composition & 0.02 & \\
Dry matter $(\mathrm{g} / \mathrm{kg})$ & & 889.3 \\
Crude protein $(\mathrm{g} / \mathrm{kg})$ & 884.0 & 187.0 \\
Crude fibre $(\mathrm{g} / \mathrm{kg})$ & 198.0 & 30.3 \\
Zinc $(\mathrm{mg} / \mathrm{kg})$ & 31.8 & 64.6 \\
Manganese $(\mathrm{mg} / \mathrm{kg})$ & 84.4 & 134.7 \\
Copper $(\mathrm{mg} / \mathrm{kg})$ & 135.4 & 21.5 \\
Calcium $(\mathrm{g} / \mathrm{kg})$ & 22.7 & 9.5 \\
Phosphorus $(\mathrm{g} / \mathrm{kg})$ & 9.8 & 4.7 \\
Lysine $(\mathrm{g} / \mathrm{kg})$ & 4.7 & 13.1 \\
Methionine $(\mathrm{g} / \mathrm{kg})$ & 13.7 & 5.3 \\
Methionine $+\mathrm{cysteine}(\mathrm{g} / \mathrm{kg})$ & 5.4 & 9.1 \\
Metabolizable energy $(\mathrm{MJ} / \mathrm{kg})$ & 9.3 & 12.7 \\
\hline & 12.6 &
\end{tabular}

Dry matter, crude protein, crude fibre, zinc, manganese and copper are analysed data.

Experimental diets were supplemented with $120 \mathrm{mg} \mathrm{Zn} / \mathrm{kg}$ in the form of zinc sulphate, zinc chelate of glycin hydrate (Zn-Gly) or zinc proteinate (Zn-Pro).

aThe vitamin/mineral premix provided per kg of complete diet: vitamin A $13500 \mathrm{IU}$, vitamin $\mathrm{D}_{3} 5000 \mathrm{IU}$, vitamin $\mathrm{K} 4.2 \mathrm{mg}$, vitamin E $60.0 \mathrm{mg}$, thiamine $5.4 \mathrm{mg}$, riboflavin $7.5 \mathrm{mg}$, pyridoxine $4.8 \mathrm{mg}$, cyanocobalamin $0.03 \mathrm{mg}$, vitamin C $75.0 \mathrm{mg}$, niacin $54.0 \mathrm{mg}$, pantothenic acid $16.5 \mathrm{mg}$, biotin $0.2 \mathrm{mg}$, folic acid $1.8 \mathrm{mg}$, choline $90.0 \mathrm{mg}$, betaine $195.0 \mathrm{mg}$, I $1.2 \mathrm{mg}$, Zn $55.0 \mathrm{mg}, \mathrm{Mn} 115.0 \mathrm{mg}$, Cu $16.5 \mathrm{mg}$, Se $0.3 \mathrm{mg}$, Co $0.5 \mathrm{mg}$, Fe $81.6 \mathrm{mg}$. ${ }^{\mathrm{b} A l l z y m e}{ }^{\circledR}$ SSF Enzyme Complex, Altech, Inc., Nicholasville, Kentucky USA 
experiment was a conventional diet commonly used in the nutrition of broiler chickens, and its composition and nutrient values are shown in Table 1. No supplemental zinc was added to BD for the control group, whereas the three other groups were fed identical BD supplemented with equal amounts of $120 \mathrm{mg} \mathrm{Zn} / \mathrm{kg}$ complete feed from either $\mathrm{Zn}$ sulphate $\left(\mathrm{ZnSO}_{4} \cdot \mathrm{H}_{2} \mathrm{O}\right.$, reagent grade, Sigma-Aldrich, USA), or $\mathrm{Zn}$ chelate of glycine hydrate (ZnGly; Glycinoplex-Zn 26\%, Phytobiotics Futterzusatzstoffe GmbH, Eltville, Germany) or Zn proteinate (Zn-Pro; Bioplex $^{\mathbb{}}-\mathrm{Zn} 15 \%$, Alltech Inc., Nicholasville, KY, USA), respectively. Feed and drinking water were offered ad libitum.

All birds were kept under similar conditions of management throughout the experiment in accordance with the guidelines for the care of fattening broiler chickens (Aviagen's Manual, 2014). The lighting schedule was maintained at $23 \mathrm{~h}$ of light and $1 \mathrm{~h}$ of darkness during the first 7 days, followed by $6 \mathrm{~h}$ of a continuous period of darkness. Relative humidity varied from 60 to $70 \%$ and the temperature regimen was adjusted to the particular age of the chickens according to breeding recommendations.

All procedures were in accordance with the European Community guidelines (Directive 2010/63/EU) on the protection of animals used for scientific purposes and the experimental protocol was approved by the Ethics Committee of the Institute of Animal Physiology SASci and by the State Veterinary and Food Office (Ro-4160/13-221).

Weekly measurements of body weight and feed intake for each replicate of the treatments were taken to calculate the average daily feed intake, average daily weight gain and feed conversion ratio (FCR). On day 35, all birds were weighed individually and the final average body weight was calculated for each treatment. Mortality within each replicate was monitored daily throughout the experiment.

At the end of the experiment, two randomly selected chickens from each replicate (a total of 12 birds from each treatment) were slaughtered by electrical stunning followed by decapitation. Blood was collected into heparinised tubes and centrifuged for plasma samples at $1,180 \times \mathrm{g}$ for $15 \mathrm{~min}$. Tissue samples (5-8 grams) were collected from identical areas of the liver, kidney and breast muscle, immediately flushed with ice-cold saline and quickly frozen. All tissue and plasma samples were stored at $-70{ }^{\circ} \mathrm{C}$ until analysis.

Dry matter (DM) of diets and tissues was determined using the standard method of drying samples at $105^{\circ} \mathrm{C}$ for $48 \mathrm{~h}$. Feed was also analyzed for crude protein and crude fibre using standard procedures (AOAC 2005; methods 976.05, 973.18).

Superoxide dismutase (SOD; EC 1.15.1.1) activity in erythrocytes and the content of haemoglobin (Hb) were analyzed in fresh blood using a commercial kit from Randox (Randox Laboratories, UK). Liver and kidney samples for analysis of total SOD and $\mathrm{Cu} / \mathrm{Zn} \mathrm{SOD}$ activities were homogenized in ice-cold buffer ( $\mathrm{pH} 7.4$ ) containing $10 \mathrm{mM}$ Tris and $0.25 \mathrm{M}$ sucrose. Subsequently, homogenates were centrifuged at $10000 \times \mathrm{g}$ for $30 \mathrm{~min}$ at $4{ }^{\circ} \mathrm{C}$ and supernatants were used for analysis of total SOD activity using the spectrophotometric method based on the autoxidation of pyrogallol (Marklund and Marklund 1974). For each sample, a parallel determination was performed in the presence of $1 \mathrm{mM} \mathrm{KCN}$ and the activity of $\mathrm{Cu} / \mathrm{Zn} \mathrm{SOD}$ was calculated as the activity inhibited by $\mathrm{KCN}$. Protein concentration in the sample supernatants was measured using the spectrophotometric method published by Bradford (1976). The TBARS levels in plasma, liver and kidney were measured using the modified fluorometric method in accordance with Jo and A hn (1998).

The contents of $\mathrm{Zn}, \mathrm{Mn}$, and $\mathrm{Cu}$ in samples were determined using a double-beam atomic absorption spectrometer (AAS-7000 series, Shimadzu, Kyoto, Japan). All samples except plasma were dried (at $105^{\circ} \mathrm{C}$ for $48 \mathrm{~h}$ ) and then ground for subsequent wet digestion in concentrated nitric acid and hydrogen peroxide (3:1) in a microwave digestion system (MWS-4, Berghof, Germany). Mineral deposition in tissue samples, $\mathrm{Zn}$ and $\mathrm{Cu}$ contents in plasma and the mineral content in diets were determined using flame atomic absorption spectrophotometry (FAAS). The AAS equipped with a graphite furnace atomizer GFA-7000 and deuterium lamp for background correction was used to measure the concentration of $\mathrm{Mn}$ in plasma.

Statistical analysis was done by one-way analysis of variance (ANOVA) with post hoc Tukey's multiple comparison test using GraphPad Prism Software (Version 2.02, 2008, USA). Differences between groups were considered significant at $P<0.05$. Values in tables are given as means \pm standard errors of the mean (SEM).

\section{Results}

The effects on growth performance of broiler chickens assessed from 0 to 35 days after supplementing the basal diet with inorganic and organic zinc are summarized in Table 2. The average daily feed intake was not influenced by supplemental $\mathrm{Zn}$. Intake of dietary $\mathrm{Zn}$ sulphate resulted in improvement of the feed conversion ratio $(P<0.001)$ and increased final body weight $(P<0.01)$ compared to birds fed the diet enriched with Zn-Gly. The average daily weight gain was significantly higher in the $\mathrm{Zn}$ sulphate group than in the unsupplemented control $(P<0.05)$ and Zn-Gly group $(P<0.001)$.

Antioxidant indicators of broilers supplemented with $\mathrm{Zn}$ from different sources are given in Table 3. Activity of SOD measured in erythrocytes was significantly elevated in the Zn-Pro group compared to control birds $(P<0.05)$ and the Zn sulphate group $(P<0.05)$. 
Table 2. Effect of different zinc sources on growing performance of broilers during the feeding period of 5 weeks (from 1 to 35 days of age).

\begin{tabular}{|c|c|c|c|c|}
\hline Indicator & $\mathrm{BD}$ & Zn-sulphate & Zn-Gly & Zn-Pro \\
\hline $\begin{array}{l}\text { Feed intake } \\
\text { (g/bird/day) }\end{array}$ & $79.60 \pm 1.06$ & $81.26 \pm 0.97$ & $80.03 \pm 1.14$ & $80.81 \pm 0.93$ \\
\hline Weight gain (g/bird/day) & $48.63 \pm 0.47^{\mathrm{a}}$ & $51.47 \pm 0.87^{\mathrm{b}}$ & $47.12 \pm 0.78^{\mathrm{a}}$ & $49.24 \pm 0.32^{\mathrm{ab}}$ \\
\hline Feed conversion ratio $(\mathrm{g} / \mathrm{g})$ & $1.64 \pm 0.01^{\mathrm{ab}}$ & $1.58 \pm 0.03^{\mathrm{a}}$ & $1.70 \pm 0.01^{\mathrm{b}}$ & $1.64 \pm 0.02^{\mathrm{ab}}$ \\
\hline $\begin{array}{l}\text { Initial body weight } \\
\text { (g/bird) }\end{array}$ & $46.47 \pm 0.32$ & $46.47 \pm 0.41$ & $46.57 \pm 0.50$ & $47.58 \pm 0.72$ \\
\hline $\begin{array}{l}\text { Final body weight } \\
\text { (g/bird) }\end{array}$ & $1733.7 \pm 16.5^{\mathrm{ab}}$ & $1832.0 \pm 30.3^{\mathrm{b}}$ & $1683.7 \pm 27.5^{\mathrm{a}}$ & $1781.4 \pm 36.1^{\mathrm{ab}}$ \\
\hline Mortality (\%) & 0.00 & 1.85 & 0.00 & 1.85 \\
\hline
\end{tabular}

Results are presented as mean \pm SEM, a,b - values in a row with different letters in superscripts are significantly different $(P<0.05)$

Table 3. Effect of different zinc sources on activity of SOD in erythrocytes and tissues, activity of Cu/Zn SOD in tissues and TBARS concentration in plasma and tissues of 35-day-old broiler chickens.

\begin{tabular}{|c|c|c|c|c|}
\hline Indicator & $\mathrm{BD}$ & Zn-sulphate & Zn-Gly & Zn-Pro \\
\hline \multicolumn{5}{|l|}{ SOD } \\
\hline Erythrocytes ( $\mu$ kat/g Hb) & $9.17 \pm 1.04^{\mathrm{a}}$ & $9.16 \pm 1.54^{\mathrm{a}}$ & $12.75 \pm 0.67^{\mathrm{ab}}$ & $14.00 \pm 1.30^{\mathrm{b}}$ \\
\hline Liver ( $\mu$ kat/mg protein) & $0.83 \pm 0.06$ & $0.91 \pm 0.06$ & $0.88 \pm 0.13$ & $0.87 \pm 0.04$ \\
\hline Kidney ( $\mu$ kat/mg protein) & $0.48 \pm 0.02$ & $0.48 \pm 0.01$ & $0.49 \pm 0.01$ & $0.50 \pm 0.01$ \\
\hline \multicolumn{5}{|l|}{$\mathrm{Cu} / \mathrm{Zn} \mathrm{SOD}$} \\
\hline Liver ( $\mu$ kat/mg protein) & $0.67 \pm 0.04$ & $0.71 \pm 0.06$ & $0.71 \pm 0.10$ & $0.67 \pm 0.03$ \\
\hline Kidney ( $\mu$ kat/mg protein) & $0.32 \pm 0.02$ & $0.32 \pm 0.01$ & $0.33 \pm 0.01$ & $0.33 \pm 0.02$ \\
\hline \multicolumn{5}{|l|}{ TBARS } \\
\hline Plasma (nmol/ml) & $0.27 \pm 0.02^{\mathrm{a}}$ & $0.25 \pm 0.01^{\mathrm{a}}$ & $0.28 \pm 0.01^{\mathrm{a}}$ & $0.37 \pm 0.02^{\mathrm{b}}$ \\
\hline Liver (nmol/g protein) & $151.5 \pm 16.8$ & $131.0 \pm 11.7$ & $135.2 \pm 12.3$ & $163.8 \pm 7.8$ \\
\hline Kidney (nmol/g protein) & $74.65 \pm 2.19$ & $71.84 \pm 6.55$ & $76.06 \pm 7.32$ & $89.74 \pm 7.03$ \\
\hline
\end{tabular}

SOD - superoxide dismutase; $\mathrm{Hb}$ - haemoglobin; TBARS - thiobarbituric acid reactive substances; Results are presented as mean \pm SEM; ${ }^{\text {a,b }}$ - values in a row with different letters in superscripts are significantly different $(P<0.05)$

Neither the SOD activity nor the $\mathrm{Cu} / \mathrm{Zn}$ SOD activity in liver and kidney were affected by dietary $\mathrm{Zn}$ supplementation. Feed supplementation with $\mathrm{Zn}$ from Zn-Pro significantly increased the TBARS levels in plasma $(P<0.01)$ compared to all other groups. There was a tendency for higher TBARS values in liver and kidney of chickens receiving Zn-Pro, however, no significant differences between treatments were observed for this indicator. The effects of various sources of dietary $\mathrm{Zn}$ on mineral concentration in plasma and tissues are presented in Table 4. Addition of $\mathrm{Zn}$-Pro to the diet significantly increased $\mathrm{Zn}$ deposition in liver $(P<0.05)$ compared to control birds fed only BD, but $\mathrm{Zn}$ concentration in plasma, kidney and breast muscle was not affected by $\mathrm{Zn}$ supplementation. No differences in concentration of $\mathrm{Mn}$ and $\mathrm{Cu}$ in plasma and tissues were found between dietary treatments.

\section{Discussion}

After 35 days of feeding experimental diets, increased average daily weight gain was observed in broilers from the $\mathrm{Zn}$ sulphate group, with an increase in the final body weight compared to 
Table 4. Concentration of zinc, manganese and copper in plasma and tissues of broilers supplemented with zinc from various sources.

\begin{tabular}{|c|c|c|c|c|}
\hline Indicators & $\mathrm{BD}$ & Zn-sulphate & Zn-Gly & Zn-Pro \\
\hline \multicolumn{5}{|l|}{ Plasma } \\
\hline $\mathrm{Zn}(\mathrm{mg} / \mathrm{l})$ & $1.88 \pm 0.07$ & $1.96 \pm 0.12$ & $1.85 \pm 0.10$ & $1.99 \pm 0.12$ \\
\hline $\operatorname{Mn}(\mu \mathrm{g} / 1)$ & $4.03 \pm 0.30$ & $3.76 \pm 0.32$ & $4.12 \pm 0.80$ & $5.19 \pm 0.87$ \\
\hline $\mathrm{Cu}(\mathrm{mg} / \mathrm{l})$ & $0.18 \pm 0.02$ & $0.21 \pm 0.02$ & $0.19 \pm 0.01$ & $0.23 \pm 0.01$ \\
\hline \multicolumn{5}{|c|}{ Liver (mg/kg DM) } \\
\hline $\mathrm{Zn}$ & $90.20 \pm 2.09^{\mathrm{a}}$ & $99.74 \pm 3.37^{\mathrm{ab}}$ & $96.67 \pm 2.03^{\mathrm{ab}}$ & $101.00 \pm 2.89^{b}$ \\
\hline $\mathrm{Mn}$ & $10.57 \pm 0.77$ & $10.65 \pm 0.67$ & $9.93 \pm 0.50$ & $11.14 \pm 0.46$ \\
\hline $\mathrm{Cu}$ & $12.28 \pm 0.32$ & $13.47 \pm 0.63$ & $12.98 \pm 0.65$ & $12.22 \pm 0.72$ \\
\hline \multicolumn{5}{|c|}{ Kidney (mg/kg DM) } \\
\hline $\mathrm{Zn}$ & $96.92 \pm 0.71$ & $96.21 \pm 2.25$ & $98.18 \pm 1.07$ & $96.40 \pm 1.04$ \\
\hline $\mathrm{Mn}$ & $10.39 \pm 0.22$ & $10.30 \pm 0.30$ & $10.82 \pm 0.25$ & $10.25 \pm 0.42$ \\
\hline $\mathrm{Cu}$ & $11.91 \pm 0.13$ & $12.49 \pm 0.15$ & $12.45 \pm 0.25$ & $12.48 \pm 0.26$ \\
\hline \multicolumn{5}{|c|}{ Breast muscle (mg/kg DM) } \\
\hline $\mathrm{Zn}$ & $19.58 \pm 0.46$ & $19.45 \pm 0.31$ & $18.96 \pm 0.30$ & $20.65 \pm 0.73$ \\
\hline $\mathrm{Mn}$ & $0.88 \pm 0.09$ & $0.93 \pm 0.10$ & $1.06 \pm 0.07$ & $0.93 \pm 0.10$ \\
\hline $\mathrm{Cu}$ & $1.75 \pm 0.23$ & $1.81 \pm 0.29$ & $1.80 \pm 0.25$ & $1.83 \pm 0.20$ \\
\hline
\end{tabular}

$\mathrm{DM}$ - dry matter; results are presented as mean $\pm \mathrm{SEM}$; ${ }^{\mathrm{a}, \mathrm{b}}$ - values in a row with different letters in superscripts are significantly different $(P<0.05)$

the Zn-Gly group. However, there was no difference in feed intake between treatments, which explains the improvement of feed conversion ratio in birds receiving inorganic $\mathrm{Zn}$. These findings show that feed supplementation with $\mathrm{Zn}$ sulphate helps to improve the performance of broiler chickens, although significant difference compared to unsupplemented control birds was observed only in the average daily weight gain. Sahraei et al. (2013) recorded higher weight gain in broilers fed similar dietary $\mathrm{Zn}$ concentrations from sulphate compared to control birds from day 22 to 28 , which is partially consistent with our results. They also reported improvement of the feed conversion ratio in the birds supplemented with Zn sulphate and ZnPro compared to the control group, and no significant difference in the final body weight between treatments, which was not confirmed in our experiment. Sunder et al. (2008) did not find any significant effect of $\mathrm{Zn}$ sulphate supplemented to the BD at graded doses up to $320 \mathrm{mg} \mathrm{Zn} / \mathrm{kg}$ for 3 weeks on broiler performance.

Several mechanisms by which $\mathrm{Zn}$ can exert its antioxidant action in a biological system have been described (Powell 2000), but one of the most important functions of $\mathrm{Zn}$ is related to its antioxidative effect mediated by $\mathrm{Cu} / \mathrm{Zn}$ SOD. Elevated activity of SOD in erythrocytes was observed in broilers fed dietary Zn-Pro compared to control birds and the $\mathrm{Zn}$ sulphate group, and was associated with higher TBARS values in plasma (Table 3). This finding could be explained by the ability of SOD to protect cells against oxidative damage (Fridovich 1995) and may in this case be a reaction of antioxidant defence mechanisms to a higher rate of lipid peroxidation. Zago and Oteiza (2001) reported that $\mathrm{Zn}$ as an important component of the antioxidant defence network prevents membrane damage from oxidation and can also partially inhibit formation of free radicals and other potentially reactive substances.

No response to $\mathrm{Zn}$ supplementation in activities of total and $\mathrm{Cu} / \mathrm{Zn} \mathrm{SOD}$ in the liver and kidney was observed in our experiment, which is in agreement with the results of Liao et al. (2013). Nevertheless, other authors have reported an increase in $\mathrm{Cu} / \mathrm{Zn}$ SOD 
activity while the concentration of malondialdehyde decreased in the liver of broilers after supplementation with $120 \mathrm{mg} \mathrm{Zn/kg}$ from Zn-Gly (Ma et al. 2010). Intake of diets with Zn dosage above the maximum EU authorized total contents (EC 2003) of this trace element in complete feed $(150 \mathrm{mg} \mathrm{Zn} / \mathrm{kg})$ did not affect TBARS values in the liver and kidney of broilers. There was only a tendency for higher values of TBARS concentration in tissues of birds receiving Zn-Pro (Table 3).

The minerals are usually administered in the form of inorganic salt which has been traditionally considered as the most cost-effective. On the other hand, organic mineral sources can be used at lower inclusion levels in the diet without a negative impact on animal health and performance, while also decreasing the excess mineral excretion to the environment (Swiatkiewicz et al. 2014). Introduction of organic or chelated sources of trace elements into animal nutrition and their potential higher bioavailability compared to inorganic sources could alter mineral deposition in tissues. In this trial, no significant differences in the plasma, liver, kidney and muscle zinc deposition were found between inorganic or organic $\mathrm{Zn}$ sources supplied to the broiler feed. Significantly higher $\mathrm{Zn}$ concentration in the liver observed in the Zn-Pro group may be connected to elevated $\mathrm{Zn}$ absorption in the intestine. $\mathrm{Yu}$ et al. (2010) found that $\mathrm{Zn}$ absorption from Zn-Pro complex is higher than that of Zn-Gly and Zn sulphate due to different chelation strength of the organic $\mathrm{Zn}$ feed additives; however, there was no significant difference in Zn tissue deposition between organic $\mathrm{Zn}$ sources used in our experiment. Plasma $\mathrm{Zn}$ concentration in the supplemented groups was equal to that in the control birds due to sufficient $\mathrm{Zn}$ content in BD. Some authors have reported that $80-84 \mathrm{mg} \mathrm{Zn} / \mathrm{kg}$ of complete feed is sufficient for optimal performance of broiler chickens (Huang et al. 2007; Sunder et al. 2008). Our results indicate that broiler performance as well as activity of $\mathrm{Cu} / \mathrm{Zn} \mathrm{SOD}$ and $\mathrm{Zn}$ deposition in tissues of the control (unsupplemented) birds were similar to those in the supplemented groups. Based on these findings we can consider $\mathrm{Zn}$ content in our BD (from 65 to $85 \mathrm{mg} \mathrm{Zn} / \mathrm{kg}$ ) as sufficient for optimal health and performance of broiler chickens.

Several studies have demonstrated (Ao et al. 2009; Sunder et al. 2011) that the extent of mineral absorption is dependent on interaction between the minerals which could either be synergistic ( $\mathrm{Zn}$ and $\mathrm{Mn}$ ) or antagonistic $(\mathrm{Zn}$ and $\mathrm{Cu}$ ). Ao et al. (2009) reported that the antagonism between $\mathrm{Zn}$ and $\mathrm{Cu}$ occurred when the inorganic forms, but not organic forms of minerals were included in a chick diet. Addition of inorganic minerals to the diet may result in reducing their absorption due to competing with each other for binding ligands and mineral uptake sites in the gut mucosa (Santon et al. 2002). It has been shown that higher $\mathrm{Zn}$ intake can inhibit intestinal absorption and consequently also hepatic uptake of $\mathrm{Cu}$ (Gonzalez et al. 2005). In this trial, the concentrations of $\mathrm{Cu}$ and $\mathrm{Mn}$ in the liver, kidney and plasma were not influenced by feed supplementation with either inorganic or organic $\mathrm{Zn}$ sources. Thus it appears that the greater $\mathrm{Zn}$ content used in the diets of our broilers did not affect the intestinal absorption of $\mathrm{Cu}$ and $\mathrm{Mn}$.

The results of our study indicate that organic zinc sources had a similar effect on mineral deposition and activity of $\mathrm{Cu} / \mathrm{Zn}$ SOD in tissues as zinc sulphate in broilers with higher dietary $\mathrm{Zn}$ intake. Based on this result we can conclude that organic sources of zinc are comparable to the traditionally used inorganic source in nutrition of broiler chickens.

\section{Acknowledgement}

This work was supported by the Slovak Research and Development Agency under the contract No. APVV0667-12.

\section{References}

Ao T, Pierce JL, Power R, Pescatore AJ, Cantor AH, Dawson KA, Ford MJ 2009: Effects of feeding different forms of zinc and copper on the performance and tissue mineral content of chicks. Poultry Sci 88: 2171-2175 
AOAC 2005: Animal Feed. In: Official Methods of Analysis. 18th Edition, Association of Official Analytical Chemists, Gaithersburg, USA, pp 27-48

Aviagen's Manual 2014: Management Handbook. http://en.aviagen.com/assets/Tech_Center/Ross_Broiler/RossBroiler-Handbook-2014i-EN.pdf

Bradford M 1976: A rapid and sensitive method for the quantitation of microgram quantities of protein utilizing the principle of protein-dye binding. Anal Biochem 72: 248-254

Cao J, Henry PR, Guo R, Holwerda RA, Toth JP, Littell RC, Miles RD, Ammerman CB 2000: Chemical characteristics and relative bioavailability of supplemental organic zinc sources for poultry and ruminants. J Anim Sci 78: 2039-2054

EC (Commission Regulation) No 1334/2003: Amending the conditions for authorisation of a number of additives in feedingstuffs belonging to the group of trace elements

Feng J, Ma WQ, Niu HH, Wu XM., Wang Y, Feng J 2010: Effects of zinc glycine chelate on growth, hematological, and immunological characteristics in broilers. Biol Trace Elem Res 133: 203-211

Fridovich I 1995: Superoxide radical and superoxide dismutases. Annu Rev Biochem 64: 97-112

Gonzalez BPE, Fong RN, Gibson CJ, Fuentealba IC, Cherian MG 2005: Zinc supplementation decreases hepatic copper accumulation in LEC rat: A model of Wilson's disease. Biol Trace Elem Res 105: 117-134

Huang YL, Lu L, Li SF, Luo XG, Liu B 2007: An optimal dietary zinc level of broiler chicks fed a corn-soybean meal diet. Poultry Sci 86: 2582-2589

Jo C, Ahn DU 1998: Fluorometric analysis of 2-thiobarbituric acid reactive substances in turkey. Poultry Sci 77: $475-480$

Liao XD, Li A, Lu, L, Liu SB, Li SF, Zhang LY, Wang GY, Luo XG 2013: Optimal dietary zinc levels of broiler chicks fed a corn-soybean meal diet from 22 to 42 days of age. Anim Prod Sci 53: 388-394

Ma W, Niu H, Feng J, Wang Y, Feng J 2010: Effects of zinc glycine chelate on oxidative stress, contents of trace elements, and intestinal morphology in broilers. Biol Trace Elem Res 142: 546-556

Marklund S, Marklund G 1974: Involvement of the superoxide anion radical in the autoxidation of pyrogallol and a convenient assay for superoxide dismutase. Eur J Biochem 47: 469-474

McDowell LR 2003: Zinc. In: McDowell LR (Ed.): Minerals in Animal and Human Nutrition. Elsevier Science, Amsterdam, Netherlands, pp 357-395

NRC (National Research Council of the National Academies) 1994: Nutrient Requirements of Poultry. $9^{\text {th }}$ Revised Edition, The National Academy Press, Washington, D.C., USA, 80 p.

Powell SR 2000: The antioxidant properties of zinc. J Nutr 130: 1447S-1454S

Rupić V, Ivandija L, Luterotti S, Dominis-Kramarić M 1997: Influence of inorganic and organic dietary zinc on its concentration in blood serum, bones and hair and on catalytical activity of some serum enzymes in pigs. Acta Vet Brno 66: 75-85

Sahraei M, Janmmohamadi H, Taghizadeh A, Moghadam GA, Rafat SA 2013: Estimation of the relative bioavailability of several zinc sources for broilers fed a conventional corn-soybean meal diet. J Poult Sci 50: 53-59

Santon S, Giannetto S, Sturniolo C, Medici V, D’Inca R, Irato P, Albergoni V 2002: Interactions between Zn and $\mathrm{Cu}$ in LEC rats, an animal model of Wilson's disease. Histochem Cell Biol 117: 275-281

Sunder GS, Kumar CV, Panda AK, Raju MVLN, Rao SVR 2011: Effect of supplemental inorganic Zn and Mn and their interactions on the performance of broiler chicken, mineral bioavailability and immune response. Biol Trace Elem Res 139: 177-187

Sunder GS, Panda AK, Gopinath NCS, Rama Rao SV, Raju MVLN, Reddy MR, Kumar ChV 2008: Effects of higher levels of zinc supplementation on performance, mineral availability, and immune competence in broiler chickens. J Appl Poult Res 17: 79-86

Swiatkiewicz S, Arczewska-Wlosek A, Jozefiak D 2014: The efficacy of organic minerals in poultry nutrition: review and implications of recent studies. World Poultry Sci J 70: 475-485

Yenice E, Mizrak C, Gültekin M, Atik Z, Tunca M 2015: Effects of organic and inorganic forms of manganese, zinc, copper, and chromium on bioavailability of these minerals and calcium in late-phase laying hens. Biol Trace Elem Res 167: 300-307

Yu Y, Lu L, Wang RL, Xi L, Luo XG, Liu B 2010: Effects of zinc source and phytate on zinc absorption by in situ ligated intestinal loops of broilers. Poult Sci 89: 2157-2165

Zago MP, Oteiza PI 2001: The antioxidant properties of zinc: interactions with iron and antioxidants. Free Radic Biol Med 31: 266-274 